\title{
Unexpected and persistent depletion of B lymphocytes CD20 following a minimum dose of anti-CD20 antibody (Rituximab)
}

\author{
Deplezione inaspettata e persistente di linfociti $B$ CD20+ dopo \\ somministrazione di una minima dose di anticorpi anti-CD20 (Rituximab)
}

\author{
V. Bruzzese, J. Pepe \\ Nuovo Regina Margherita Hospital, Rome, Italy; \\ Department of Medicine of ASL RM/A, CHU of Internal Medicine, Section of Rheumatology
}

\begin{abstract}
RIASSUNTO
Viene descritto il caso di una donna affetta da artrite reumatoide resistente ai comuni DMARDs ed agli Anti TNF alfa, che con una minima dose di Rituximab ha presentato una persistente e profonda deplezione dei linfociti CD20. La dose di Rituximab infusa è stata di soli $50 \mathrm{mg}$ a causa dell'insorgenza di reazione allergica. Alla luce di questa osservazione, alcune importanti e speculative considerazioni potrebbero essere fatte, ma solo dopo conferma con una casistica più ampia.
\end{abstract}

Reumatismo, 2009; 61(4):306-308

\section{INTRODUCTION}

$\mathrm{R}$ ituximab is a chemeric murine/human anti-B lymphocyte antigen CD20 monoclonal antibody used in the treatment of rheumatoid arthritis resistant to treatment by one or more anti TNF-alpha therapies (1).

The recommended dose for an efficient depletion of the B CD 20 lymphocytes in rheumatoid arthritis is two infusions of $1000 \mathrm{mg}$, with the second infusion being administered two weeks after the first.

At this dose, one obtains a rapid and persistent depletion of CD 20 cells, with repopulation occurring, on the average, in about eight months (2).

Here, we present a case of a woman treated with only $50 \mathrm{mg}$ of rituximab, who underwent both a rapid and pronounced reduction of B CD 20 lymphocytes.
Indirizzo per la corrispondenza:

Dott. Vincenzo Bruzzese

Via Bosco degli Arvali, 24

00148 Roma

E-mail: vinbruzzese@ tiscali.it

\section{CLINICAL CASE}

C.V. is a woman of 48 years of age, affected by rheumatoid arthritis since 2004. Treatment with Methotrexate (15 mg/week) and Sulfasalazine (2 $\mathrm{g} /$ day) provided good results for a period of about two years, after which the patient experienced the worsening of symptoms also shown by radiographic findings with increased level of acutephase reactant. We decided to begin an anti TNFalpha therapy (Etanercept $50 \mathrm{mg} /$ week), in combination with Methotrexate ( $15 \mathrm{mg} /$ week). We obtained good control of the disease until February 2008 , when the patient again started to complain of prolonged suffering with polyarticular inflammation which seriously compromised her quality of life.

Blood tests revealed elevated ESR $(41 \mathrm{~mm} / 1 \mathrm{~h})$ and CRP and X-ray of the hands and wrists showed a progression in the damage compared to the previous year's exam. The DAS 28 was 6,2. The immunoglobulin $\operatorname{IgG}$, IgA and IgM were normal.

We decided to suspend treatment with Etanercept and start with Rituximab, associated with Methotrexate. As a precaution, a count was made of the CD 19+B lymphocytes which showed a nor- 
mal level: 211 cells/ul (expected range 100-410 cells/ul), with a percentage of $8,3 \%$ (range $7,00-16$, $0)$. For flow cytometry, a I.L. cytometry has been used, with $10.000 \mathrm{CD} 3+$ number of events counted or 300 seconds, we used monoclonal CD19 antibodies and a CD45 FITC/SS gating strategy.

In May 2008, 2 months after which Etanercept was stopped, the patient was hospitalized to undergo her first infusion of Rituximab (1000 mg; the first $500 \mathrm{mg}$ diluted in $500 \mathrm{cc}$ of physiological solution) preceded by the conventional pre-medication with Paracetamol, Chlorphenamine and Metilprednisolone.

After only $50 \mathrm{ml}$ of infusion, the patient presented signs of skin rash and itching in the face area rapidly extending to the neck and trunk area, with sensation of difficulty in swallowing and a slight sense of constriction in the chest. We immediately stopped the infusion of Rituximab, and we treated the patient with Metilprednisolone. The symptoms decreased after a half an hour and disappeared completely over the next two hours. At a distance of 24 hours, the patient experienced skin rash in the face area and required an additional dose of cortisone.

Twenty days after the infusion of Rituximab (approximately $50 \mathrm{mg}$ ) we again tested the patient for CD19+B lymphocytes, which resulted in 2 cells/ul, with a percentage of $0,1 \%$. Follow-up monthly controls always revealed a pronounced depletion of CD20 lymphocytes, and the last control six months after the infusion showed 36 cells/ul with a percentage of $1,3 \%$.

In any case, the patient did not show any clinical and objective signs regarding remission of the disease. Likewise, tests for controlling the disease's activity did not reveal remission. In fact, DAS28 was 5,8 .

\section{DISCUSSION}

There is no simple explanation at to how such a small (minimum) dose of Rituximab could have determined such a pronounced and prolonged depletion of BCD 20 lymphocytes, the same as if the patient had been treated with the standard dose which is foreseen for treating rheumatoid arthritis. The patient showed an idiosyncratic type of allergic reaction to the molecule.

The reaction was definitely not that of Cytokine release syndrome, which is much more serious and accompanied by hypotension, dyspnea, hypoxia, fever, and pulmonary edema (3). The eventuality of such a reaction is, in any case, very rare in cases of rheumatoid arthritis around the order of $(<1 \%)$, on the contrary to that of acute allergic reactions which is around $26 \%$ at the first infusion, decreasing considerably with successive infusions (4).

In conclusion, our patient showed a pronounced and prolonged depletion of B CD20+ lymphocytes following a minimum dose of Rituximab. Such a case has never been reported before in literature. This case is interesting and leads to a number of considerations/questions.

First: if a peripheral depletion of CD-20 is obtained from a minimum dose of Rituximab, can this be considered of therapeutic importance, or, in any case, can the use of the drug at a lower dosage be hypothesized? Second: is the above mentioned peripheral depletion of CD-20, which is induced by the minimum dose of the drug, also accompanied by the same depletion of CD-20 at synovial level? Lastly: regarding the allergic reaction to the drug, is it always accompanied by a CD-20 depletion?

To answer these questions, observations across a wider group of cases is required.

\section{SUMMARY}

This study describes a woman patient suffering from rheumatoid arthritis which was resistant to treatment with the most commonly used DMARDs and anti-TNF alfa drugs, however following the administration of a minimum dose of Rituximab the patient showed a persistent and complete depletion of CD 20 lymphocytes. The dose of Rituximab administered to the patient was halted at $50 \mathrm{mg}$ due to the onset of an allergic reaction. Based on these observations, a number of important speculations are possible, which however would require a larger number of case histories for their confirmation.

Parole chiave - Reazione allergica, dose minima di Rituximab, deplezione CD20.

Key words - Allergic reaction, minimum dose of Rituximab, depletion CD20. 


\section{REFERENCES}

1. Cohen SB, Emery P, Greenwald MW, Dougados M, Furie RA, Genovese MC, et al. Rituximab for rheumatoid arthritis refractory to anti-tumor necrosis factor therapy: results of a multi center, randomized, doubleblind, placebo-controlled, phase III trial evaluating primary efficacy and safety at twenty-four weeks. Arthritis Rheum 2006; 54: 2793-806.

2. Leandro MJ, Cambridge G, Ehrenstein MR, Edwards JC. Reconstitution of peripheral blood B cells after de- pletion with rituximab in patients with rheumatoid arthritis. Arthritis Rheum 2006; 54: 613-20.

3. Winkler U, Jensen M, Manzke O, Schulz H, Diehl V, Engert A. Cytokine relase syndrome in patients with $\mathrm{B}$ cell chronic lymphocyte leukaemia and high lymphocyte counts after treatment with an anti CD 20 monoclonal antibody (rituximab, IDEC-C2B8). Blood 1999; 94: 2217-24.

4. Keystone E, Roy F, Emery P, Furst ED, van Vollehoven R, Balthon J et al. Safety and Efficacy of Additional Courses of Rituximab in Patients With Active Rheumatoid Arthritis. Arthritis Rheum 2007; 56: 3896-908. 